\title{
Melatonin as an Antioxidant and Immunomodulator in Atopic Dermatitis-A New Look on an Old Story: A Review
}

\author{
Andrzej Kazimierz Jaworek ${ }^{1, *}$, Jacek Cezary Szepietowski ${ }^{2} \mathbb{D}$, Przemysław Hałubiec ${ }^{3} \mathbb{D}^{\mathbb{D}}$, Anna Wojas-Pelc $^{1}$ \\ and Jolanta Jaworek ${ }^{4}$ \\ 1 Department of Dermatology, Jagiellonian University Medical College, 31-501 Cracow, Poland; \\ anna.wojas-pelc@uj.edu.pl \\ 2 Department of Dermatology, Venereology and Allergology, Wroclaw Medical University, \\ 50-368 Wroclaw, Poland; jacek.szepietowski@umed.wroc.pl \\ 3 Student Scientific Group, Department of Dermatology, Jagiellonian University Medical College, \\ 31-501 Cracow, Poland; przemyslawhalubiec@gmail.com \\ 4 Department of Medical Physiology, Faculty of Health Sciences, Jagiellonian University Medical College, \\ 31-126 Cracow, Poland; jolanta.jaworek@uj.edu.pl \\ * Correspondence: andrzej.jaworek@uj.edu.pl
}

check for

updates

Citation: Jaworek, A.K.;

Szepietowski, J.C.; Hałubiec, P.;

Wojas-Pelc, A.; Jaworek, J. Melatonin

as an Antioxidant and

Immunomodulator in Atopic

Dermatitis-A New Look on an Old

Story: A Review. Antioxidants 2021,

10, 1179. https://doi.org/10.3390/

antiox10081179

Academic Editor: Gaia Favero

Received: 10 June 2021

Accepted: 22 July 2021

Published: 24 July 2021

Publisher's Note: MDPI stays neutral with regard to jurisdictional claims in published maps and institutional affiliations.

Copyright: (C) 2021 by the authors. Licensee MDPI, Basel, Switzerland. This article is an open access article distributed under the terms and conditions of the Creative Commons Attribution (CC BY) license (https:/ / creativecommons.org/licenses/by/ $4.0 /)$.

\begin{abstract}
Atopic dermatitis (AD) is common inflammatory dermatosis, typically with chronic and recurrent course, which significantly reduces the quality of life. Sleep disturbances are considered to be remarkably burdensome ailments in patients with $\mathrm{AD}$, and are routinely included during assessment of disease severity. Therefore, endogenous substances engaged in the control of circadian rhythms might be important in pathogenesis of AD and, possibly, be used as biomarkers of disease severity or even in development of novel therapies. Melatonin (MT), the indoleamine produced by pineal gland (but also by multiple other tissues, including skin), plays a pivotal role in maintaining the sleep/wake homeostasis. Additionally, it possesses strong antioxidant and anti-inflammatory properties, which might directly link chronic skin inflammation and sleep abnormalities characteristic of AD. The objective of this work is to systematically present and summarize the results of studies (both experimental and clinical) that investigated the role of MT in the AD, with a focus on the antioxidant and immunomodulatory effects of MT.
\end{abstract}

Keywords: atopic dermatitis; melatonin; sleep disturbances

\section{Introduction}

Atopic dermatitis (AD, commonly referred to as eczema) is considered to be the most frequent inflammatory skin disease, with global prevalence of 15 to $20 \%$ among children and up to $10 \%$ in adults [1-3]. The total burden of this dermatosis (i.e., disability adjusted life-years) is the largest of all skin diseases [4]. Both the incidence and the severity of $\mathrm{AD}$ are influenced by the environmental factors such as air pollutants or animal-derived allergens [5].

The clinical presentation of the patient with AD typically involves chronic and relapsing erythematous patches with exudation, often accompanied by papules, oedema and crusting with characteristic, age-dependent, anatomical distribution [6-8]. A foundation for theses abnormalities is persistent inflammatory state with skin xerosis. With time, hypoand hyperpigmentation occurs, replacing the healing lesions. Likewise, chronic scratching results in lichenification and fissuring. In children (the onset is usually between 2-6 months of life) areas involved are: face and cheeks, arms and wrists, and legs. Parallel with the increasing age of the patient, skin changes tend to localize on popliteal flexures and hands, feet, neck and the periocular region. The main reported symptom, being referred to as the hallmark of the disease, is intense pruritus (leading to the itch-scratch cycle) $[9,10]$.

The pathophysiology of AD involves the overlapping effects of impaired epidermal barrier (resulting in increased water loss and skin dryness, which could be addressed, for 
example, to the low expression of filaggrin) and immunological aberrations (polarization of immunological response towards $\mathrm{T}_{\mathrm{H}}$ 2-dependent immunity, with interleukins (IL) such as IL-4, IL-13, IL-25 and IL-31 playing a prominent role, which activates Janus kinases (JAK) and triggers synthesis of IgE) [11,12]. Determination of the initial component is not straightforward, however, the division of AD into the extrinsic (initially immunological abnormalities) and intrinsic (initially abnormal skin barrier) types seems to address that problem [13].

Commonly, AD is accompanied by the other atopic diseases, i.e., associated with type 1 Gell-Coombs immediate hypersensitivity, such as: allergic asthma, allergic rhinoconjunctivitis or food allergy. The specific sequence of their development is described as the "atopic march" [14]. A higher tendency to develop skin infections (S. aureus is considered to be usually responsible for dysbiosis of skin microbiota observed in AD), autoimmune and rheumatologic disorders, psychiatric conditions (anxiety and depression) and, possibly, cardiovascular disorders has also been observed [15].

Sleep loss is an undisputed feature of AD, being considered during assessment of disease severity using the Scoring Atopic Dermatitis (SCORAD) scale [16]. The prevalence of sleep disturbances among AD patients was assessed as $50-80 \%$ in children and 30-90\% in adults $[2,17,18]$. Abnormalities may be observed at any stage of sleep, such as prolonged sleep onset latency, nighttime awakenings, difficulty waking up, and serious daytime sleepiness. Data acquired by objective techniques (i.e., polysomnography (PSG) or actigraphy) indicate that sleep efficiency among AD subjects is significantly lower than in healthy controls, with reduced non-rapid eye movement (NREM) phase of sleep cycle [19]. Some additional sleep-specific ailments are observed more frequently in AD patients compared to the healthy population, including obstructive sleep apnea (OSA) and parasomnias. The quality of life (QoL) is drastically tampered by sleep disorders, resulting in overwhelming frustration and exhaustion of both patients and their families (for example sleep disorders in AD children strongly correlate with maternal depression) [20]. Although the main AD symptoms, such as excessive itch and the consequent scratching, seem to sufficiently explain the abnormal sleep pattern among patients, the observation that only about $15 \%$ of AD children were reported to be woken up by the urge to scratch, raised suspicion that actually more complex mechanisms are involved [17]. A vast variety of interleukins (particularly IL-4 and IL-31), chemokines (CXCL9 and CXCL10), neuropeptides (substance P), hormones (cortisol) and even allergen specific IgE (for example against Dermatophagoides pteronyssinus) were linked to abnormal sleep in AD [18]. Another molecule which provisionally plays a crucial role in sleep disturbance in AD is melatonin (MT).

Since its discovery by dermatologist Aaron Lerner in 1958, melatonin ( $N$-acetyl-5methoxytryptamine) became one of most fascinating substances [21,22]. This indoleamine was best recognized as a product of pineal gland but further studies revealed that this substance with an evolutionary conserved structure could be produced in many human tissues and in every living species. Melatonin was detected in the bacteria, fungi, plants, vertebrates and also in invertebrates. Its primary function is to serve as first-line defense against internal and environmental oxidative stressors [22-25]. Identification of MT in archaea and prokaryotes (Cyanobacteria) indicates that this substance was present on the Earth at the very early stage of evolution, when intensive ultra-violet (UV) radiation and high concentration of oxygen in the atmosphere posed a serious danger to living organisms. Melatonin's ability to neutralize free radicals protected life and made the evolution of living creatures possible [22,26-28].

Synthesis of MT and its release from the pineal gland is driven by the light-dark cycle via the retino-hypothalamic (suprachiasmatic nucleus) axis and sympathetic nerves. Plasma levels of MT reach the highest values at night (between 1.00 and 3.00 a.m.) increasing up to $300 \mathrm{pg} / \mathrm{mL}$, whereas light reduces MT release [29]. Because of its rhythmic fluctuations, MT is considered a main body regulator of circadian rhythms. Production of this indoleamine decreases with age, and its circadian rhythm of secretion disappears in older individuals [30]. 
MT has been identified in many mammalian cells and tissues such as: gastrointestinal and reproductive systems, macrophages, lymphocytes, endothelial cells, retina, salivary glands, kidneys, thyroid, pancreas, liver, spleen, airway epithelium, carotid body and brain [24,31-37].

MT is implicated in numerous aspects of skin homeostasis and its concentration in the skin is several times higher than in the blood [38]. Skin protection against UVB radiation is one of most known effects of melatonin, presented in numerous in vitro and in vivo studies [39-42]. MT is able to enhance the skin barrier by stimulation of keratin expression [38] and because of its effect on fibroblast, it appears as a promising agent in wound healing $[43,44]$. Antiaging action of MT in the skin is in line with its antioxidant/antiinflammatory effects through inhibition of nuclear factor $\kappa B(\mathrm{NF}-\kappa \mathrm{B})$ and reactive oxygen species (ROS) formation, suppression of metalloproteinases (MMPs) and cyclooxygenase 2 (COX2) [45].

Skin possess a specific melatonergic system, which was evaluated by detection in the skin cells of genes and enzymes involved in MT synthesis; arylalkylamino- $N$-acetylserotonin-transferase (AA-NAT) and $N$-acetylserotonin O-methyltransferase (ASMT) $[46,47]$. In addition to enzymatic production, MT synthesis in the skin might be triggered by UVA-induced free radical oxidation of L-tryptophan converted to hydroxytryptophan. Among the metabolic derivatives of melatonin, there are: 6-hydroxymelatonin (6-OHM), 4hydroxymelatonin (4-OHM), $N^{1}$-acetyl- $N^{1}$-formyl-5-metoxykynuramine (AFMK), and $N^{1}$ acetyl-5-methoxy-kynuramine (AMK). All the above metabolites are strong antioxidants, in the same way as their maternal molecule $[48,49]$.

MT, as it is highly lipophilic, easily penetrates through cell membranes, to directly affect intracellular organelles. Along with this direct action of MT its biological effects are also mediated by its receptors MT1R, MT2R, MT3R [50-52]. MT membrane receptors MT1R and MT2R belong to G-protein-coupled receptors. Receptor MT3 is the enzyme quinone reductase 2 (QR2), involved in antioxidant action of MT [53]. Both receptors MT1R and MT2R have been identified in mammalian skin, eccrine glands, and blood vessels; however, MT1R is predominant and it was found also in the differentiating layer of epidermis [54].

An additional group of MT receptors are orphan nuclear receptors (retinoid orphan receptor, ROR), which have been identified in skin cells [52,55]. The implication of these receptors on the effects of MT is the matter of discussion. Some authors questioned their role as MT receptors, explaining that natural ligands for these receptors are sterols, which are structurally different from MT [50]. Experimental studies by Dai et al. demonstrated that $\operatorname{ROR} \alpha / \beta$ could be involved in pathogenesis of atopic dermatitis [56].

MT is generally accepted as versatile protector against oxidative damage. Mitochondria are main cellular source of ROS and reactive nitrogen species (RNS). MT controls the generation of these free radicals through modulation of mitochondrial genes expression and improves activity of mitochondrial respiratory chain [22,28,51,52,57-60]. It should be emphasized that MT is also synthesized in these organelles by aforementioned enzymes, AA-NAT and ASMT [61]. Actually, mitochondrial concentration of MT is virtually independent of the pineal gland synthesis (although mitochondria are capable of up-taking MT by transporters PEPT1/2) and mitochondria-derived MT is generally not released into systemic circulation. Surprisingly, mitochondrial MT constitutes more than $95 \%$ of total MT production [60]. On the other hand, MT plays a pivotal role in the regulation of mitochondrial biogenesis and in maintaining their homeostasis (referred to as mitoprotection), which involves, for example, reduced cytochrome c release and lowered $\mathrm{Ca}^{2+}$ overload $[62,63]$.

The antioxidant activity of MT in mitochondria involves direct scavenging of ROS, as well as activation of sirtuin 3 , which deacetylates (therefore, activates) mitochondrial superoxide dismutase 2 (SOD2) [61]. As the free radicals acts only over the short distance from their site of origin (i.e., their half-life time is approximately $\sim 10^{-9} \mathrm{~s}$, as is the case for $\mathrm{HO}^{\bullet}$ ), only antioxidants present in the same cell's compartment can effectively quench them. In mitochondria, MT seems to be the main executor of this role [60]. MT is able to protect mitochondrial membrane from the peroxidation of cardiolipin and formation 
of mitochondrial permeability transition pores (mPTPs), to maintain the mitochondrial membrane potential, formation of adenosine triphosphate (ATP), and prevent cells form apoptosis $[60,64,65]$. That activity is supported by the activation of MT1R receptors located on the outer mitochondrial membrane.

The complex activity of MT in mitochondria results in alleviation of the cytokine storm (for example through repression of mTOR and HIF- $1 \alpha$, and inhibition of oxidative glycolysis), synergistically with MT produced peripherally by pineal gland [63]. It is interesting that MT could also induce MPTP and is able to activate the apoptotic process in cancer cell lines [66]. Reiter et al. [67] pointed out that the circadian rhythm of MT synthesis (present also in mitochondria) contributes significantly to difference in the metabolic pattern between the day and night, with oxidative phosphorylation augmented by MT.

Protective effects of MT on cellular structures, mainly on deoxyribonucleic acid (DNA), are attributed to its potent antioxidant ability [68]. MT exerts its antioxidant action in multiple ways:

1. MT, by donating an electron, acts a direct scavenger of reactive species. In this way it neutralizes variety of free radicals such as $\mathrm{HO}^{\bullet}$, alkyl radicals $\left(\mathrm{RO}^{\bullet}\right)$, peroxyradicals $\left(\mathrm{ROO}^{\bullet}\right)$ and ${ }^{\bullet} \mathrm{NO}$, as well as non-radical oxidants: singlet oxygen $\left({ }^{1} \mathrm{O}_{2}\right)$, hydrogen peroxide $\left(\mathrm{H}_{2} \mathrm{O}_{2}\right)$ and peroxynitrate $\left(\mathrm{ONOO}^{-}\right)$.

2. MT indirect effect is related to the stimulation of the antioxidant enzymes such as: superoxide dismutase, catalase (CAT), glutathione peroxidase (GPx), glutathione reductase (GPd), glutathione S-transferase (GTS), heme oxygenase 1 (HO-1), $\gamma$-glutamylcysteine synthase $(\gamma$-GCS). This indirect effect is dependent on the activation of nuclear erythroid 2-related factor (Nrf2) by MT and was demonstrated in many cells, including keratinocytes [69-74].

3. MT was demonstrated to inhibit pro-oxidative enzyme xanthine oxidase $(\mathrm{XO})$, which is known to generate radicals in tissues exposed to microwave radiation [75,76].

4. MT is able to accelerate the repair of ROS-induced DNA lesion. It enhances the expression of DNA repairing genes, such as 8-oxoguanidine glycosylase (OGG1), and affects the mechanisms involved in DNA repair pathways [77,78].

Antioxidant effect MT is accompanied by its anti-inflammatory activity. MT reduces the inflammatory process through widespread mechanisms involving modulation of intracellular signaling pathways, inhibition of proinflammatory NF- $\mathrm{KB}$, and activation of antioxidant Nrf2 pathways. Experimental studies demonstrated that MT reduces generation of proinflammatory cytokines and enzymes such as: inducible nitric oxide synthase (iNOS), COX2, tumor necrosis factor $\alpha$ (TNF $\alpha$ ), interleukin $1 \beta$ (IL-1 $\beta$ ), Il-4, IL-6, IL-13, or IL-18 [79-81]. Recent studies have presented MT's anti-inflammatory action related to the suppression of inflammasome NLRP3, which amplifies the NF- $\mathrm{kB}$-mediated inflammatory response. Inhibition of NLRP3 by MT prevented from the activation of pro-L-1 $\beta$ and pro-IL-18, thus blocking the initiation of proinflammatory cytokine cascade [82-85].

The above discussed mechanisms and effects of MT are summarized in Figure 1.

It should be mentioned that MT was earlier presented in in vitro studies as immunomodulatory molecule. Studies on monocytes and T cells demonstrated that MT upregulated expression of proinflammatory cytokines, in particular IL-17, which subsequently initiates release of other interleukins (TNF $\alpha, \mathrm{IL}-1 \beta, \mathrm{IL}-6)[83,86,87]$. 


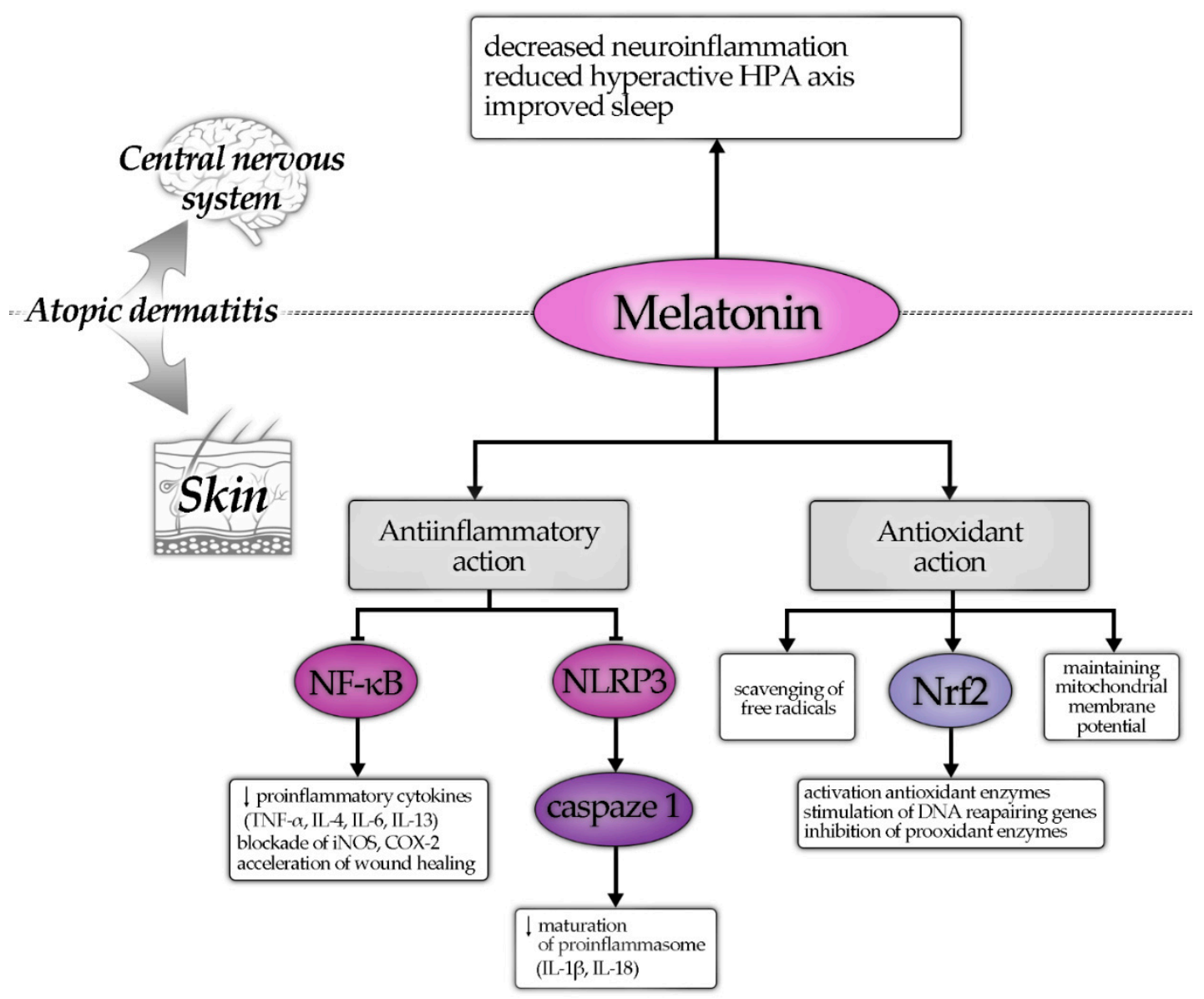

Figure 1. Protective effects of melatonin on atopic dermatitis-hypothetic mechanisms of action. Note: the arrow $(\downarrow)$ means, that the decrease in given entity is observed.

\section{Materials and Methods}

This review was based on the analysis of the PubMed database [88]. Articles were searched through Medical Subject Headings (MeSH) thesaurus, looking for the publications related to MT and AD. The key terms "melatonin" AND ("atopic dermatitis", OR "atopic eczema", OR "eczema") were used for main search.

The initial search on MT and AD selected 28 articles, 31 publications on MT and atopic eczema and 12 articles on MT and eczema. Selected articles were published from 1988 to 2021. Most of the articles from the above three searches were the same papers. The abstracts of articles in which title suggested the relation between MT and AD were selected and read. Publications identified from the abstract as irrelevant to the topic, review papers, or these not written in English were excluded. Sole abstracts without any access to the article, were also excluded, except one.

Articles selected for analysis were carefully read, and their references were examined to identify the publications, that could be included in the review.

\section{Results}

Articles searched from PubMed regarding melatonin MT and AD were sparse. For final analysis, 11 original papers and a single abstract were selected. Among these papers, there were 8 that presented results of clinical studies and 3 describing experimental studies on animals. A single abstract was included into analysis, because it was the first published information on MT and AD that we were able to find, and because of few publications on the above topic.

The first report on MT and AD that we were able to find comes from 1988. Subsequent clinical papers were published: 3 in 2007, 1 in 2014, 2 in 2016, 1 in 2018, and the last one 
in 2020. Three experimental studies on NC/Nga atopic such as mice and melatonin were performed in 2009, 2017 and 2018.

Two clinical studies employed adult AD patients, while the rest of papers presented observations on atopic children and adolescents. Study groups consisted of 20-75 persons. Most studies presented results obtained from an Asian population: two were from China, two from Japan, one from India, Turkey and Iran. Two additional studies originated from Europe (Germany and Spain).

Tables 1-3 present the main data that form the results of this study.

Table 1. Summary of findings from the observational human studies.

\begin{tabular}{|c|c|c|c|c|c|c|c|c|}
\hline $\begin{array}{l}\text { Author and } \\
\text { Reference }\end{array}$ & Year & $\begin{array}{c}\text { Patients } \\
\text { Enrolled }(N)\end{array}$ & Treatment & $\begin{array}{l}\text { Parameters } \\
\text { Tested }\end{array}$ & $\begin{array}{c}\text { Tissue } \\
\text { Samples }\end{array}$ & $\begin{array}{c}\text { MT } \\
\text { Measurement }\end{array}$ & Method & Results \\
\hline $\begin{array}{c}\text { Schwarz } \\
\text { et al. } \\
\text { [89] }\end{array}$ & 1988 & $\begin{array}{l}\text { adults with } \\
\text { AD (18) }\end{array}$ & $\mathrm{n} / \mathrm{a}$ & MT & blood & $\begin{array}{c}\text { endogenous MT } \\
\text { measured every } \\
2 \mathrm{~h} \text { for } 24 \mathrm{~h}\end{array}$ & not given & $\begin{array}{l}\text { low serum MT in } \\
6 \text { patients and } \\
\text { abolished } \\
\text { circadian rhythm } \\
\text { of its release; } \\
\text { decreased } \\
\text { nocturnal MT } \\
\text { peak, in } \\
\text { additional } 8 \text { AD } \\
\text { patients; only } \\
4 \text { patients } \\
\text { showed a normal } \\
\text { pattern of MT } \\
\text { secretion }\end{array}$ \\
\hline $\begin{array}{l}\text { Kimata } \\
\text { [90] }\end{array}$ & 2007 & $\begin{array}{l}\text { women with } \\
\text { AD, mild } \\
\text { SCORAD } \\
(48)\end{array}$ & $\begin{array}{c}\text { laughter, } \\
\text { viewing a } \\
\text { humorous } \\
\text { film }\end{array}$ & MT, IgE & $\begin{array}{l}\text { breast milk, } \\
\text { serum }\end{array}$ & $\begin{array}{c}\text { endogenous MT } \\
\text { measured at } \\
11.00 \text { p.m., at } \\
2.00 \text { a.m., at } \\
0.50 \text { a.m. }\end{array}$ & ELISA (MT) & $\begin{array}{l}\text { low basal MT in } \\
\text { milk of AD } \\
\text { patients, } \\
\text { however } \\
\text { stimulated MT in } \\
\text { milk was similar } \\
\text { to healthy } \\
\text { control; } \\
\text { decreased } \\
\text { nocturnal MT } \\
\text { peak in these } \\
\text { patients; higher } \\
\text { IgE in AD } \\
\text { mothers }\end{array}$ \\
\hline $\begin{array}{l}\text { Kimata } \\
\text { [91] }\end{array}$ & 2007 & $\begin{array}{l}\text { children } \\
\text { with AD, } \\
\text { moderate } \\
\text { SCORAD } \\
\quad(24)\end{array}$ & $\begin{array}{l}\text { laughter, } \\
\text { viewing a } \\
\text { humorous } \\
\text { film }\end{array}$ & $\begin{array}{l}\text { MT, sleep, } \\
\text { SCORAD }\end{array}$ & saliva & $\begin{array}{c}\text { endogenous MT } \\
\text { measured every } \\
2 \mathrm{~h} \text { from } \\
10.0 \text { p.m., to } \\
6.00 \text { a.m. }\end{array}$ & $\begin{array}{c}\text { ELISA (MT), } \\
\text { ELISA } \\
(\text { INF- } \gamma) \text { sleep } \\
\text { question- } \\
\text { naire }\end{array}$ & $\begin{array}{l}\text { low basal and } \\
\text { stimulated MT in } \\
\text { AD patients; } \\
\text { decreased } \\
\text { nocturnal MT } \\
\text { peak; increased } \\
\text { INF- } \gamma \text {; better } \\
\text { sleep correlated } \\
\text { with higher MT }\end{array}$ \\
\hline $\begin{array}{c}\text { Munoz- } \\
\text { Hoyoz et al. } \\
\text { [92] }\end{array}$ & 2007 & $\begin{array}{c}\text { children } \\
\text { with AD (40) } \\
\text {-severe (20) } \\
\text {-asymptomatic } \\
(20)\end{array}$ & $\mathrm{n} / \mathrm{a}$ & $\begin{array}{c}\text { MT, } \\
\beta \text {-endorphin }\end{array}$ & blood & $\begin{array}{l}\text { endogenous MT } \\
\text { measured at } \\
9.00 \text { a.m. and at } \\
9.00 \text { p.m. }\end{array}$ & RIA (MT) & $\begin{array}{c}\text { low MT at } \\
9.00 \text { p.m.; } \\
\text { nocturnal MT at } \\
9.00 \text { p.m. slightly, } \\
\text { but non } \\
\text { significantly } \\
\text { lower than } \\
\text { control; MT in } \\
\text { asymptomatic } \\
\text { group similar to } \\
\text { control; } \\
\text { 3-endorphin } \\
\text { decreased }\end{array}$ \\
\hline
\end{tabular}


Table 1. Cont.

\begin{tabular}{|c|c|c|c|c|c|c|c|c|}
\hline $\begin{array}{l}\text { Author and } \\
\text { Reference }\end{array}$ & Year & $\begin{array}{c}\text { Patients } \\
\text { Enrolled }(N)\end{array}$ & Treatment & $\begin{array}{c}\text { Parameters } \\
\text { Tested }\end{array}$ & $\begin{array}{c}\text { Tissue } \\
\text { Samples }\end{array}$ & $\begin{array}{c}\text { MT } \\
\text { Measurement }\end{array}$ & Method & Results \\
\hline $\begin{array}{c}\text { Chang et al. } \\
\text { [93] }\end{array}$ & 2014 & $\begin{array}{l}\text { children and } \\
\text { adolescents } \\
\text { with AD, } \\
\text { moderate } \\
\text { SCORAD } \\
(72)\end{array}$ & $\mathrm{n} / \mathrm{a}$ & $\begin{array}{l}\text { MT, sleep, } \\
\text { IgE, pruritus, } \\
\text { scratching } \\
\text { movement }\end{array}$ & urine & $\begin{array}{l}\text { endogenous MT } \\
\text { measured as 6- } \\
\text { sulfatoxymelatonin } \\
\text { (in morning } \\
\text { urine samples) }\end{array}$ & $\begin{array}{l}\text { ELISA (MT), } \\
\text { actigraphy, } \\
\text { polysomnog- } \\
\text { raphy, sleep } \\
\text { question- } \\
\text { naire }\end{array}$ & $\begin{array}{l}\text { nocturnal MT } \\
\text { higher in AD } \\
\text { patients than in } \\
\text { controls; lower } \\
\text { MT correlated } \\
\text { with poor sleep } \\
\text { efficiency, longer } \\
\text { onset sleep } \\
\text { latency, } \\
\text { decreased NREM } \\
\text { sleep, more sleep } \\
\text { fragmentation; } \\
\text { IgE in serum } \\
\text { increased }\end{array}$ \\
\hline $\begin{array}{l}\text { Uysal et al. } \\
\text { [94] }\end{array}$ & 2016 & $\begin{array}{c}\text { children } \\
\text { with AD (73) } \\
\text {-mild (12) } \\
\text {-moderate } \\
(22) \\
\text {-severe (39) }\end{array}$ & $\mathrm{n} / \mathrm{a}$ & $\begin{array}{l}\text { MT, NO, } \\
\text { malondialde- } \\
\text { hyde (MDA), } \\
\text { SCORAD }\end{array}$ & blood & $\begin{array}{c}\text { endogenous MT, } \\
\text { measured at } 9.00 \\
\text { a.m. }\end{array}$ & $\begin{array}{c}\text { ELISA (MT), } \\
\text { ELISA } \\
(\mathrm{MDA}), \\
\text { reduction } \\
\text { method } \\
(\mathrm{NO})\end{array}$ & $\begin{array}{l}\text { increased MT in } \\
\text { AD patients, } \\
\text { comparing to } \\
\text { control; MT } \\
\text { lower in severe } \\
\text { AD, than in mild; } \\
\text { NO decreased in } \\
\text { all AD patient; } \\
\text { MDA similar to } \\
\text { control }\end{array}$ \\
\hline $\begin{array}{c}\text { Devadasan } \\
\text { et al. } \\
\text { [95] }\end{array}$ & 2020 & $\begin{array}{l}\text { children } \\
\text { with AD (30) } \\
\text {-mild, } \\
\text {-moderate } \\
\text {-severe }\end{array}$ & $\mathrm{n} / \mathrm{a}$ & $\begin{array}{c}\text { MT, } \\
\text { SCORAD, } \\
\text { MDA, SOD, } \\
\text { GPx }\end{array}$ & blood & $\begin{array}{c}\text { endogenous MT } \\
\text { measured at } \\
9.00 \text { a.m. }\end{array}$ & $\begin{array}{c}\text { ELISA (MT), } \\
\text { RANDOX } \\
\text { (SOD, GPx), } \\
\text { TBA-TCA- } \\
\text { HCl } \\
\text { (MDA) }\end{array}$ & $\begin{array}{l}\text { increased MT } \\
\text { and MDA } \\
\text { comparing to } \\
\text { control; SOD, } \\
\text { GPx increased, } \\
\text { but } \\
\text { insignificantly; } \\
\text { none of } \\
\text { parmeters } \\
\text { correlated with } \\
\text { SCORAD }\end{array}$ \\
\hline
\end{tabular}

Table 2. Summary of findings from the experimental human studies.

\begin{tabular}{|c|c|c|c|c|c|c|c|}
\hline $\begin{array}{l}\text { Author and } \\
\text { Reference }\end{array}$ & Year & $\begin{array}{c}\text { Patients } \\
\text { Enrolled }(N)\end{array}$ & $\begin{array}{c}\text { Experimental } \\
\text { Treatment }\end{array}$ & $\begin{array}{c}\text { Parameters } \\
\text { Tested }\end{array}$ & $\begin{array}{l}\text { Tissue } \\
\text { Samples }\end{array}$ & Method & Results \\
\hline $\begin{array}{c}\text { Chang et al. } \\
\text { [96] }\end{array}$ & 2016 & $\begin{array}{c}\text { children and } \\
\text { adolescent } \\
\text { with AD, } \\
\text { moderate } \\
\text { SCORAD (38) }\end{array}$ & $\begin{array}{c}\text { exogenous } \\
\text { MT given } \\
3 \mathrm{mg} / \text { day for } \\
4 \text { weeks before } \\
\text { bedtime }\end{array}$ & $\begin{array}{l}\text { MT, sleep, IgE, } \\
\text { SCORAD }\end{array}$ & urine & $\begin{array}{l}\text { ELISA (MT), } \\
\text { actigraphy }\end{array}$ & $\begin{array}{l}\text { MT application } \\
\text { reduced SCORAD, } \\
\text { decreased sleep } \\
\text { onset latency; } \\
\text { improvement of } \\
\text { sleep was not } \\
\text { correlated with } \\
\text { SCORAD; serum IgE } \\
\text { was similar to control }\end{array}$ \\
\hline $\begin{array}{l}\text { Ardakani et al. } \\
\text { [97] }\end{array}$ & 2018 & $\begin{array}{l}\text { children with } \\
\text { AD, moderate } \\
\text { and severe } \\
\text { SCORAD (35) }\end{array}$ & $\begin{array}{c}\text { exogenous } \\
\text { MT given } \\
6 \mathrm{mg} / \text { day for } \\
6 \text { weeks before } \\
\text { bedtime }\end{array}$ & $\begin{array}{c}\text { SCORAD, } \\
\text { sleep, CRP, IgE }\end{array}$ & blood & $\begin{array}{c}\text { SCORAD, } \\
\text { sleep } \\
\text { questionnaire }\end{array}$ & $\begin{array}{l}\text { MT application } \\
\text { reduced SCORAD, } \\
\text { and IgE, improved } \\
\text { total sleep scores; } \\
\text { CRP and } \\
\text { pruritus were } \\
\text { similar to control }\end{array}$ \\
\hline
\end{tabular}


Table 3. Summary of findings from the experimental animal studies.

\begin{tabular}{|c|c|c|c|c|c|c|}
\hline $\begin{array}{l}\text { Author and } \\
\text { Reference }\end{array}$ & Year & $\begin{array}{c}\text { Experimental } \\
\text { Models }\end{array}$ & Experimental Design & Material and Method & $\begin{array}{c}\text { Parameters } \\
\text { Tested }\end{array}$ & Results \\
\hline $\begin{array}{c}\text { Kim et al. } \\
\text { [98] }\end{array}$ & 2009 & $\mathrm{NC} / \mathrm{Nga}$ mice & $\begin{array}{l}\text { sensitization with } 2,3- \\
\text { dinitrofluorobenzene } \\
\text { (DNFB) followed by } \\
\text { repeated application } \\
\text { of DNFB on the skin + } \\
\text { MT 10, or } 20 \text { mg/day } \\
\text { i.p. for } 2 \text { weeks }\end{array}$ & $\begin{array}{l}\text { skin, blood, CD4+ } \\
\text { cells isolated from } \\
\text { animals, histologic } \\
\text { analysis, ELISA kits } \\
\text { for interleukins } \\
\text { and IgE }\end{array}$ & $\begin{array}{l}\text { skin lesions, IgE, } \\
\text { IL-4, INF- } \gamma\end{array}$ & $\begin{array}{l}\text { MT treatment reduced } \\
\text { skin lesions, such as } \\
\text { hypertrophy, } \\
\text { hyperkeratosis and } \\
\text { inflammatory cell } \\
\text { infiltration, as well as } \\
\text { serum IgE; MT } \\
\text { treatment inhibited } \\
\text { production of IL-4 and } \\
\text { INF- } \gamma \text { by activated } \\
\text { CD4 } 4^{+} \text {cells }\end{array}$ \\
\hline $\begin{array}{l}\text { Park et al. } \\
\text { [99] }\end{array}$ & 2017 & $\begin{array}{l}\text { NC/Nga mice, } \\
\text { mouse HT } 22 \\
\text { hippocampal cell } \\
\text { culture, } \\
\text { rat brain primary } \\
\text { hypothalamic } \\
\text { neuronal cells } \\
\text { (RPHN) }\end{array}$ & $\begin{array}{l}\text { sensitization with 2,3- } \\
\text { dinitrochlorobenzene } \\
\text { (DNCB) followed by } \\
\text { repeated application } \\
\text { of DNCB on the skin } \\
\text { + MT } 20 \mathrm{mg} \text { /day } \\
\text { orally with or without } \\
\text { cortisone } 20 \text { mg/day } \\
\text { orally for } 6 \text { weeks; } \\
\text { incubation of cells } \\
\text { with various } \\
\text { concentrations of } \\
\text { cortisol }\end{array}$ & $\begin{array}{l}\text { skin, blood, brain } \\
\text { samples, cell cultures, } \\
\text { PCR, Western blot, } \\
\text { immunochemistry, } \\
\text { immunocyto- } \\
\text { chemistry, } \\
\text { immuno- } \\
\text { fluorescence, } \\
\text { comercial kits }\end{array}$ & $\begin{array}{l}\text { skin lesions; } \\
\text { scratching } \\
\text { behavior; neuroin- } \\
\text { flammation and } \\
\text { neuronal cells } \\
\text { viability; IgE; } \\
\text { MT1R, CRH, } \\
\text { POMC, ACTH; } \\
\text { COX2, iNOS; } \\
\text { TNF } \alpha, \text { IL-4, IL-1 } \alpha\end{array}$ & $\begin{array}{l}\text { MT treatment reduced } \\
\text { skin lesions, scratching } \\
\text { behavior and serum IgE; } \\
\text { MT treatment reversed } \\
\text { atopic stress-induced } \\
\text { neuronal damage; } \\
\text { increased reduced by } \\
\text { stress MT and MT1R in } \\
\text { the brain and skin and } \\
\text { supressed } \\
\text { neuroinflammation }\end{array}$ \\
\hline $\begin{array}{l}\text { Park et al. } \\
\text { [100] }\end{array}$ & 2018 & $\begin{array}{l}\text { NC/Nga mice, } \\
\text { SH-SY5Y human } \\
\text { neuronal cell } \\
\text { culture }\end{array}$ & $\begin{array}{l}\text { DNCB model + MT as } \\
\text { above, incubation of } \\
\text { cells with various } \\
\text { concentrations of } \\
\text { cortisol or MT }\end{array}$ & $\begin{array}{l}\text { brain tissues, human } \\
\text { neuronal cell culture, } \\
\text { PCR, Western blot, } \\
\text { immunohisto- } \\
\text { chemistry, } \\
\text { commercial kits }\end{array}$ & $\begin{array}{c}\text { MT, CRH, CRHR } \\
\text { 1, ACTH, } \\
\text { norepinephrine, } \\
\text { dopamine, } \\
\text { dopamine } \\
\text { ß-hydroxylase, } \\
\text { tyrosine } \\
\text { hydroxylase }\end{array}$ & $\begin{array}{l}\text { MT reversed induced by } \\
\text { AD stress-increase in } \\
\text { norepinephrine and } \\
\text { dopamine, and } \\
\text { hyperactivity of } \\
\text { hypothalamic- } \\
\text { hypophyseal-adrenal } \\
\text { (HPA) axis, MT } \\
\text { corrected dysregulated } \\
\text { dopamine and } \\
\text { noradrenline system, } \\
\text { which is related to } \\
\text { attention- } \\
\text { deficit/hyperactivity } \\
\text { disorder (ADHD) } \\
\text { caused by atopic } \\
\text { mouse model }\end{array}$ \\
\hline
\end{tabular}

\subsection{MT Secretion and Blood Level in Patients with $A D$}

Studies on the melatonin secretion and its blood concentration in AD patients presented opposite results.

The first report suggesting possible implication of MT in pathophysiology of AD was reported by Schwarz et al. [89] in 1988. Their study evaluated serum MT concentrations in adult patients with AD. This study involved a limited number of patients (18 persons). In six of the AD patients, the serum level of MT was lower than in control subjects and the circadian rhythm of MT was abolished. An additional eight patients presented a reduced nocturnal peak of serum MT. Only four patients presented normal secretion pattern of MT. Authors related abnormalities of MT secretion to the low activity of the sympathetic nervous system.

This observation was supported by two original studies concerning MT secretion by mammary and salivary glands. In both the above secretions, the MT concentrations originating from patients suffering from $\mathrm{AD}$ were decreased compared to the healthy subjects $[90,91]$. One of these studies involved 48 lactating women with mild AD and the same number of healthy mothers. MT was measured in their milk under basal conditions and following nonstandard stimulation, which was the presentation of $87 \mathrm{~min}$ humorous 
films with Charlie Chaplin. The control women observed weather information. MT was measured every $2 \mathrm{~h}$, during the night. The duration of the experiment was 2 weeks. MT secretion to the milk had a peak at 2.00 a.m. and reached $10.7 \mathrm{pg} / \mathrm{mL}$ in AD mothers and $15.6 \mathrm{pg} / \mathrm{mL}$ in healthy women. Concentration of MT in the milk of all mothers viewing humorous films was significantly elevated, and peak value in AD group was similar to control (19.9 pg/mL vs. $20.8 \mathrm{pg} / \mathrm{mL}$ ) [90]. The author did not explain the mechanism of this phenomenon; however, he suggested that feeding babies with milk with a higher concentration of MT may reduce the allergic response in infants with AD.

In the next study, the author, using the same model of experiment as that used for the lactating women (viewing humorous films), investigated MT concentration on saliva. The study group enrolled $40 \mathrm{AD}$ children with mild and moderate severity of this disease. The author observed lower concentration of nocturnal (measured at 2.00 a.m.) MT in saliva of patients with $\mathrm{AD}(26.5 \mathrm{pg} / \mathrm{mL})$, as compared to healthy control $(58.6 \mathrm{pg} / \mathrm{mL})$. Additionally, stimulated secretion of MT was diminished in atopic children $(51.9 \mathrm{pg} / \mathrm{mL}$ vs. $66.7 \mathrm{pg} / \mathrm{mL}$ ) [91].

Decreased serum melatonin MT was also reported in a subsequent report, which was carried out on 40 atopic children and adolescents. Reduction in daily MT serum concentration was demonstrated in the AD group, compared to healthy control $(11.7 \mathrm{pg} / \mathrm{mL}$ vs. $30.5 \mathrm{pg} / \mathrm{mL})$. Nocturnal peak of MT was lower in AD patients $(34.5 \mathrm{pg} / \mathrm{mL})$, than in the compared healthy group $(43.5 \mathrm{pg} / \mathrm{mL})$, but the difference was not significant [92].

More recent studies presented opposite results. Nocturnal MT secretion, assessed as urinary concentration of 6-sulfatoxymelatonin at night, was higher in children with moderate AD, compared to in analogous healthy group [93]. Additionally, two successive clinical trials revealed that serum MT measured in the morning in AD children was increased, compared to the control patients [94,95]. The serum MT levels achieved in $\mathrm{AD}$ children was $1.6 \mathrm{pg} / \mathrm{mL}$, whereas in healthy control was $0.92 \mathrm{pg} / \mathrm{mL}$ [95]. In the second study, MT serum concentration in atopic patients reached $2.1 \mathrm{pg} / \mathrm{mL}$, which was significantly higher than in control- $1.6 \mathrm{pg} / \mathrm{mL}$ [94]. In one of these studies, the correlation between blood MT and severity of disease was observed, with lower concentration of MT found in persons suffering from more severe AD [94]. However, in another recent study, such a relationship has not been found [95].

\subsection{Oxidative Stress Markers, Melatonin and Severity of Atopic Dermatitis}

The oxidative stress indicators measured in AD patients included: MDA, NO and antioxidant enzymes: SOD and GPx, and a positive correlation was found between $\mathrm{NO} /$ melatonin and malondialdehyde/melatonin ratios $(\mathrm{r}=0.511, p<0.0001)[94,95]$. All markers were measured in the patient's serum. MDA was measured in two studies and the results were opposite. In one of these studies, the values of MDA were low, and MDA in AD children was significantly higher $(0.12 \mathrm{nmol} / \mathrm{L})$ as compared to healthy individuals $(0.06 \mathrm{nmol} / \mathrm{L})$ [95]. The authors reported no correlation between MDA value and severity of disease. In the next study, MDA in AD children was not significantly different from healthy control and reached $1.28 \mathrm{nmol} / \mathrm{L}$ in investigated AD patients vs. $1.30 \mathrm{nmol} / \mathrm{L}$ in control. On the contrary, serum NO level was decreased in AD patients $(28.90 \mathrm{nmol} / \mathrm{L})$ when compared to control value $(33.55 \mathrm{nmol} / \mathrm{L})$. Additionally, NO/MT ratio was markedly lower in study group (2.26) than in control (4.97) [94].

Antioxidant enzymes GPx and SOD were higher in atopic children $(246.52 \mathrm{pg} / \mathrm{mL}$, and $9.48 \mathrm{pg} / \mathrm{mL}$, respectively) than in the control group $(209.54 \mathrm{pg} / \mathrm{mL}$ and $7.86 \mathrm{pg} / \mathrm{mL}$, respectively), but the differences were not statistically significant [95].

In the mice model, DNCB-induced neuroinflammation treatment with MT reduced both hippocampal COX2 (from $116.4 \%$ to $105.4 \%$ of control) and iNOS (from $124.6 \%$ to $107.4 \%$ of control) [100]. 


\subsection{Melatonin and Sleep Quality in Patients with Atopic Dermatitis}

It is commonly accepted that MT facilitates a transition to sleep in humans. The relationship between MT and sleep was investigated in four analyzed studies on MT in $\mathrm{AD}$ patients. The obtained results were not univocal, and differences related to the details of presented data have been found. In three of publications, higher secretion of MT and its increased serum concentration was positively correlated to the sleep quality $[91,93,96]$. In AD children with low serum level of MT, disturbances of sleep such as decreased nonrapid eye movement (NREM) phase, and longer onset of sleep latency were recorded. It was perceived that a higher SCORAD index was significantly correlated with poorer sleep, shorter total sleep time and more sleep fragmentation. Authors concluded that higher SCORAD predicted poor sleep efficiency [93]. However, in a later study of the same group of authors, the association between improvement of SCORAD index and sleep has not been found [96]. In their recent study, Ardakani and his group demonstrated the lack of correlation between serum MT and improvement of sleep-onset latency in young patients with AD, but it should be highlighted that MT alleviated AD (improved SCORAD) independent of the disease's negative effect on sleep [97].

In one study, $\beta$-endorphin in serum was measured and was found to be lower in atopic children $(26.24 \mathrm{pg} / \mathrm{mL})$ than in control $(45.33 \mathrm{pg} / \mathrm{mL})$ [92].

\subsection{Effect of MT Supplementation on Atopic Dermatitis}

Two separate studies evaluated the effect of MT supplementation on the severity of $\mathrm{AD}$ and sleep disturbances. In both studies, MT was given to the patients before sleep time every day for several weeks. In the study by Chang et al. [96] MT at dose of $3 \mathrm{mg} /$ day was applied for 4 weeks, which produced a significant increase in the nocturnal urinary MT level. In the second study, carried out by Ardakani at al. [97], the dose of MT was doubled (6 mg/day) and such treatment of AD children was continued for 6 weeks. MT application resulted in a significant reduction in SCORAD index in both studies. In the first of these studies, the reduction in sleep-onset latency was noted, yet this did not correlate with attenuation of disease severity expressed as SCORAD [96]. Supplementation with MT did not significantly affect pruritus score, sleep fragmentation, mobility in sleep, total sleep time and CRP value in both studies.

Opposite effect of MT supplementation on serum IgE was observed. In one study serum IgE concentration in patients with AD was not affected by MT, despite of reduced SCORAD [96]. In another study, serum IgE was reduced [97].

\subsection{Results of Experimental Studies on the Effect of MT on $A D$}

$\mathrm{NC} / \mathrm{Nga}$ mice are useful models of human $\mathrm{AD}$, as the inflammatory response of their skin resembles that seen in human with atopic skin inflammation. For the experiments, animals are sensitized with 2,3-dinitrofluorobenzene (DNFB), or with 2,3-dinitrochlorobenzene (DNCB) followed by subsequent application of one of these substances.

Systemic application of MT (10 or $20 \mathrm{mg} / \mathrm{kg}$ per day) for 2 or more weeks significantly decreased skin lesions and reduced serum IgE $[98,99]$. In experiments in vitro with CD4 ${ }^{+}$ cells isolated from lymph nodes of mice treated with MT, the production of IL- 4 and INF- $\gamma$ was diminished compared with production of these interleukins secreted by $\mathrm{CD} 4^{+}$cells obtained from control, untreated with MT mice [98].

Two experimental studies investigated the effect of prolonged (6 weeks) MT treatment on the stress, neuroinflammation and neuronal damage in NC/Nga-atopic-like mouse model. In these animals, treatment with DNFB increased activity of HPA axis, that was evidenced by the high serum concentrations of $\mathrm{CRH}$, POMC, ACTH and cortisol. Levels of the above markers of HPA axis were also augmented in hypothalamus and hippocampus of NC/Nga atopic mice. In the brain of these animals increased expression and protein signals for iNOS, COX2, IL- $1 \alpha$, INF- $\alpha$ and amplification of microglial activity were detected. Expression signals and proteins of MT synthesis and MT1R in the skin and in the hypothalamus were reduced. MT administration to NC/Nga atopic mice suppressed 
hyperactive HPA axis, restored the level of MT and its receptor in the brain and skin, and reduced neuroinflammation [99].

In another study by the same group of authors, the increased activity of the HPA axis in NC/Nga was assessed by measurement of catecholamines synthesis. This was evidenced by high activity of enzymes participating in this process-dopamine $\beta$-hydroxylase and tyrosine hydroxylase - and by increased concentrations of noradrenaline and dopamine in the different areas of brain. Such changes resulted in ADHD. Treatment with MT reversed the above abnormalities in the levels of neuromediators in the brain and inhibited ADHD behavior [100].

\section{Discussion}

The results of our study show that implication of MT in the pathogenesis of AD is still unexplained. One of reasons is that publications concerning this subject are sparse. We were able to find only eight clinical studies and three experimental papers from between 1988 and 2020. In addition, the data from clinical observations are sometimes incoherent.

Measurements of MT blood concentration in patients with AD presented contrasting results. In some earlier published papers, authors have shown that serum MT was significantly decreased in AD patients, comparing to the healthy subjects [89,92]. Additionally, secretion of this indoleamine into saliva and into breast milk of patients with AD reached lower values, than in the control $[90,91]$.

On the contrary, studies performed during the last 5-6 years demonstrated that MT concentrations in serum and in urine were higher than those observed in the control groups [93-95]. These discrepancies could be partially related to the differences between groups of patients participating in the particular studies, to the samples collection and methods of melatonin measurement.

Patients with AD included into study group were characterized by moderate or mild SCORAD, but sometimes children with mild, moderate, and severe AD were located in the same study group [91]. Participants in one group were small children and adolescents, even though MT secretion changes with age, and the puberty stage is characterized by a decline in MT secretion [101]. Additionally, in some of studies the number of patients was limited to $20-30$ persons $[99,100]$. Such limited study populations could produce difficulties with interpretation of results.

Samples were collected during the night, when MT secretion reaches the peak [89-91], but also in the morning at 9:00 a.m. [94,95] or in the morning and in the evening [92]. Analyzed material originated from the blood, saliva, breast milk and urine and different methods were used to determine MT concentrations. In most of studies, MT was measured using immunoenzymatic ELISA method [90,91,93-95], but in one study RIA was engaged [92]. In urine samples, MT metabolite, 6-sulfatoxymelatonin was measured [93,96].

In addition to the above discrepancies, the results of studies demonstrated that serum concentration of melatonin MT was lower in patients with severe AD having high SCORAD, than in those with mild or moderate disease activity [92,94]. Perhaps in the patients with mild and moderate SCORAD MT was utilized to neutralize free radicals and because of this process, their intensity of inflammation was reduced [91]. It is likely that in addition to sleep regulation by MT, this indolamine plays an important role as an antioxidant alleviating the inflammatory changes in AD. It is noteworthy that an increase in psychic condition of $\mathrm{AD}$ patients (laughing, when viewing a humorous film), resulted in a significant augmentation in MT peak secretion and decrease in blood IgE [90]. In the other study, low serum MT was correlated with decreased $\beta$-endorphin secretion [92]. The release of both MT and $\beta$-endorphin are affected by adrenergic stimulation and both systems (melatonergic and opiate) are interconnected [102]. It is likely that low affinity of one of these systems depressed the other and low secretion of MT is associated with reduced opiate production and release.

It could be hypothesized that high secretion of MT and its higher serum concentration might reflect the activation of an innate defensive antioxidant system, which counteracted 
skin inflammatory process. This is in accordance with the decreased MDA level and augmentation (although insignificant) of antioxidant enzymes in these patients [95]. However, in the other study, high serum MT was not paralleled to the decrease in serum MDA [94].

Anti-inflammatory effects of MT occur inseparably of its antioxidant function. The aforementioned impact on MDA level, as well as reduction in NO release, possibly contribute to the alleviation of the inflammatory state [94]. Additional evidence is acquired from the experimental studies, that showed the reduction in IL-4 and IFN- $\gamma$ production [98], as well as alleviated neuroinflammation (i.e., reduced level of COX2 and iNOS) [99] after supplementation with MT. These results are in line with the previous data and could be addressed to the inhibition of NF- $\mathrm{KB}$ and NLRP3 inflammasome. It is conceivable that MT combats inflammation systemically rather than locally (e.g., in skin and neural system), which explains the benefits of MT supplementation on both skin symptoms and sleep disturbances in patients with $\mathrm{AD}[96,97]$.

Four analyzed papers investigated the correlation between MT and sleep [91,93,96,97]. It was shown that lower MT concentrations were associated with poor sleep quality, whereas supplementation with adequate dose of MT improved the sleep (this improvement was observed independently from method of assessment, i.e., sleep questionnaire [97], or actigraphy [96]). Nevertheless, reductions in SCORAD and serum IgE were detected only when a higher dose of MT (6 mg/day) was given to the patients [97].

Results of experimental studies support and complete the above clinical observations. MT administration reduced inflammatory process in the skin, which was suggested by decreased SCORAD in AD patients [97] and histological skin assessment in NC/Nga atopic-like mice, decrease in serum IgE, and decline in secretion of IL-4 and INF- $\gamma$ from activated $\mathrm{CD}^{+}$cells $[98,99]$. In addition, MT supplementation was shown in experimental studies to reduce atopic-related stress, and stress-induced neuronal damage, and reversed dysregulated catecholamines production.

\section{Conclusions}

Considering several limitations and difficulties in the interpretation of materials presented in the analyzed studies some conclusions could be made:

1. Based on previous and recent publications [103], it could be stated that AD is related to the increase in oxidative stress, and since MT is powerful antioxidant, its implication in the defense of inflammatory reaction of AD patients is very likely.

2. Lower serum MT is correlated with more severe inflammation in AD patients.

3. MT supplementation improves sleep and, with application of adequate dose, reduces SCORAD and serum IgE in AD patients.

It is worth remembering that MT derivatives share the antioxidant and anti-inflammatory effects of its maternal molecules, and AFMK, AMK and 6-OHM are even more potent antioxidants than MT itself. Generation of these particles prolongs and strengthens the effects of MT, creating MT cascade which appears one of most important mechanisms of innate immunity in various tissues [104-107].

Author Contributions: Conceptualization, A.K.J., J.J.; methodology, A.K.J., J.J.; formal analysis, A.K.J., J.C.S., P.H., A.W.-P., J.J; resources, P.H.; data curation, A.K.J., J.C.S., J.J.; writing-original draft preparation, A.K.J., J.J.; writing—review and editing, A.K.J., P.H., J.J.; visualization and figures, P.H.; supervision, J.C.S., A.W.-P., J.J. All authors have read and agreed to the published version of the manuscript.

Funding: This research received no external funding.

Conflicts of Interest: The authors declare no conflict of interest.

\section{References}

1. Ständer, S. Atopic Dermatitis. N. Engl. J. Med. 2021, 384, 1136-1143. [CrossRef] [PubMed]

2. Silverberg, J.I.; Garg, N.K.; Paller, A.S.; Fishbein, A.B.; Zee, P.C. Sleep disturbances in adults with eczema are associated with impaired overall health: A US population-based study. J. Investig. Dermatol. 2015, 135, 56-66. [CrossRef] 
3. Weidinger, S.; Beck, L.A.; Bieber, T.; Kabashima, K.; Irvine, A.D. Atopic dermatitis. Nat. Rev. Dis. Primers 2018, 4. [CrossRef]

4. Laughter, M.R.; Maymone, M.B.C.; Mashayekhi, S.; Arents, B.W.M.; Karimkhani, C.; Langan, S.M.; Dellavalle, R.P.; Flohr, C. The global burden of atopic dermatitis: Lessons from the Global Burden of Disease Study 1990-2017. Br. J. Dermatol. 2020, 184, 304-309. [CrossRef]

5. Jaworek, A.K.; Szafraniec, K.; Jaworek, M.; Hałubiec, P.; Wojas-Pelc, A. Is the presence of a fur animal an exacerbating factor of atopic dermatitis in adults? Pol. Merkur. Lek. 2020, 48, 19-22.

6. Weidinger, S.; Novak, N. Atopic dermatitis. Lancet 2016, 387, 1109-1122. [CrossRef]

7. Langan, S.M.; Irvine, A.D.; Weidinger, S. Atopic dermatitis. Lancet 2020, 396, 345-360. [CrossRef]

8. Andersen, R.M.; Thyssen, J.P.; Maibach, H.I. Qualitative vs. quantitative atopic dermatitis criteria-in historical and present perspectives. J. Eur. Acad. Dermatol. Venereol. 2016, 30, 604-618. [CrossRef] [PubMed]

9. Yew, Y.W.; Thyssen, J.P.; Silverberg, J.I. A systematic review and meta-analysis of the regional and age-related differences in atopic dermatitis clinical characteristics. J. Am. Acad. Dermatol. 2019, 80, 390-401. [CrossRef]

10. Mack, M.R.; Kim, B.S. The itch-scratch cycle: A neuroimmune perspective. Trends. Immunol. 2018, 39, 980-991. [CrossRef] [PubMed]

11. Jaworek, A.K.; Szafraniec, K.; Zuber, Z.; Wojas-Pelc, A.; Jaworek, J. Interleukin 25, thymic stromal lymphopoietin and house dust mites in pathogenesis of atopic dermatitis. J. Physiol. Pharmacol. 2020, 71. [CrossRef]

12. Martin, M.J.; Estravís, M.; García-Sánchez, A.; Dávila, I.; Isidoro-García, M.; Sanz, C. Genetics and epigenetics of atopic dermatitis: An updated systematic review. Genes 2020, 11, 442. [CrossRef]

13. Tokura, Y. Extrinsic and intrinsic types of atopic dermatitis. J. Derm. Sci. 2010, 58, 1-7. [CrossRef] [PubMed]

14. Yang, L.; Fu, J.; Zhou, Y. Research progress in atopic march. Front. Immunol. 2020, 11, 1907. [CrossRef]

15. Eichenfield, L.F.; Tom, W.L.; Chamlin, S.L.; Feldman, S.R.; Hanifin, J.M.; Simpson, E.L.; Bergman, J.N.; Cohen, D.E.; Cooper, K.D.; Cordoro, K.M. Guidelines of care for the management of atopic dermatitis: Section 1. Diagnosis and assessment of atopic dermatitis. J. Am. Acad. Dermatol. 2014, 70, 338-351. [CrossRef] [PubMed]

16. Severity Scoring of Atopic Dermatitis: The SCORAD Index. Dermatology 1993, 186, 23-31. [CrossRef] [PubMed]

17. Chang, Y.-S.; Chiang, B.-L. Sleep disorders and atopic dermatitis: A 2-way street? J. Allergy Clin. Immunol. 2018, 142, 1033-1040. [CrossRef] [PubMed]

18. Dogan, D.G.; Canaloglu, S.K.; Kivilcim, M.; Kum, Y.E.; Topal, E.; Catal, F. Sleep patterns of young children with newly diagnosed atopic dermatitis. Adv. Derm. Allergol. 2017, 34, 143-147. [CrossRef] [PubMed]

19. Hon, K.L.; Leung, T.F.; Ma, K.C.; Li, A.M.; Wong, Y.; Yin, J.A.; Fok, T.F. Resting energy expenditure, oxygen consumption and carbon dioxide production during sleep in children with atopic dermatitis. J. Dermatolog. Treat. 2005, 16, 22-25. [CrossRef] [PubMed]

20. Meltzer, L.J.; Moore, M. Sleep disruptions in parents of children and adolescents with chronic illnesses: Prevalence, causes, and consequences. J. Pediatr. Psychol. 2008, 33, 279-291. [CrossRef]

21. Claustrat, B.; Brum, J.; Chazot, G. The basic physiology and pathophysiology of melatonin. Sleep Med. Rev. 2005, 9, 11-24. [CrossRef] [PubMed]

22. Tan, D.X.; Manchester, L.C.; Liu, X.; Rosales-Corral, S.A.; Acuna-Castroviejo, D.; Reiter, R.J. Mitochondria and chloroplasts as the original sites of melatonin synthesis: A hypothesis related to melatonin's primary function and evolution in eukariotes. J. Pineal Res. 2013, 54, 127-138. [CrossRef]

23. Back, K.; Tan, D.X.; Reiter, R.J. Melatonin biosynthesis in plants: Multiple pathways catalyze tryptophan to melatonin in the cytoplasm of chloroplasts. J. Pineal Res. 2016, 61, 426-437. [CrossRef] [PubMed]

24. Hardeland, R.; Poeggeler, B. Melatonin and synthetic melatonergic agonists: Actions and metabolism in the central nervous system. Cent. Nerv. Syst. Agents Med. Chem. 2012, 12, 189-216. [CrossRef] [PubMed]

25. Tan, D.X.; Zheng, X.; Kong, J.; Manchester, L.C.; Haderland, R.; Kim, S.J.; Xu, X.; Reiter, R.J. Fundamental issue related to the origin of melatonin and melatonin isomers during evolution: Relation to their biological functions. Int. J. Mol. Sci. 2014, 15, 15858-15890. [CrossRef] [PubMed]

26. Tan, D.X.; Haderland, R.; Manchester, L.C.; Korkmas, A.; Ma, S.; Rosales-Corral, S.; Reiter, R.J. Functional roles of melatonin in plants, and perspectives in nutritional and agricultural science. J. Exp. Bot. 2012, 63, 577-597. [CrossRef]

27. Haderland, R.; Balzer, I.; Poeggler, B.; Fuhrberg, B.; Uria, H.; Behrmann, G.; Wolf, R.; Meyer, T.J.; Reiter, R.J. On the primary functions of melatonin in evolution: Mediation of photoperiodic signals in a unicell, photooxidation, and scavenging of free radicals. J. Pineal Res. 1995, 18, 104-111.

28. Reiter, R.J.; Rosales-Corral, S.; Tan, D.X.; Jou, M.J.; Galano, A.; Xu, B. Melatonin as a mitochondria-targeted antioxidant: One of evolution's best ideas. Cell. Mol. Life. Sci. 2017, 74, 3863-3881. [CrossRef] [PubMed]

29. Kurowska, A.; Bodys-Cupak, I.; Staszkiewicz, M.; Szklarczyk, J.; Zalewska-Puchala, J.; Klis-Kalinowska, A.; Makara-Studzińska, M.; Majda, A. Interleukin 6 and melatonin as predictors of cognitive, emotional and functional ageing in older people. Int. J. Environ. Res. Pub. Health 2020, 17, 3623. [CrossRef] [PubMed]

30. Cardinali, D.P. Melatonin and healthy aging. Vitam. Horm. 2021, 115, 167-188.

31. Chen, C.Q.; Fichna, J.; Bashashati, M.; Li, Y.Y.; Storr, M. Distribution, function and physiological role of melatonin in the lower gut. World J. Gastroenterol. 2011, 17, 3888-3898. [CrossRef]

32. Messner, M.; Huether, G.; Lorf, T. Presence of melatonin in the human hepatobiliary tract. Life Sci. 2001, 69, 543-551. [CrossRef] 
33. Bubenik, G.A. Gastrointestinal melatonin: Localization, function, and clinical relevance. Dig. Dis. Sci. 2002, 47, 2336-2348. [CrossRef] [PubMed]

34. Wang, J.; Zhu, T.; Ma, X.; Wang, Y.; Liu, J.; Li, G.; Liu, Y.; Ji, P.; Liu, G. Melatonergic systems of AANAT, melatonin, and its receptor MT2 in the corpus luteum are essential for reproductive success in mammals. Biol. Reprod. 2021, 104, 430-444. [CrossRef]

35. Acuna-Castroviejo, D.; Escames, G.; Venegas, C.; Diaz-Casado, M.E.; Lima-Cabello, R.; Lopez, L.C.; Rosales-Corral, S.; Tan, D.X.; Reiter, R.J. Extrapineal melatonin: Sources, regulation and potential functions. Cell. Mol. Life Sci. 2014, 71, 2997-3025. [CrossRef] [PubMed]

36. Muxel, S.M.; Pires-Lapa, M.A.; Monteiro, A.W.A.; Cecon, E.; Tamura, E.K.; Floeter-Winter, L.M.; Markus, R.P. NF-kB drives the synthesis of melatonin in RAW 264.7 macrophages by inducing the transcription of the arylalkylamine- $N$-acetyltransferase (AA-NAT) gene. PLoS ONE, 2012; 7, e52010.

37. Carrillo-Vico, A.; Calvo, J.R.; Abreu, P.; Lardone, P.J.; Garcia-Maurino, S.; Reiter, R.J.; Guerrero, J. Evidence of melatonin synthesis by human lymphocytes and its physiological significance: Possible role as intracrine, autocrine, and/or paracrine substance. FASEB J. 2004, 18, 537-539. [CrossRef] [PubMed]

38. Kim, T.K.; Lin, Z.; Tidwell, W.J.; Li, W.; Slominski, A. Melatonin and its metabolites accumulate in the human epidermis in vivo and inhibit proliferation and tyrosinase activity in epidermal melanocytes in vitro. Mol. Cell. Endocrinol. 2013, 404, 1-8. [CrossRef]

39. Fischer, T.W.; Scholz, G.; Knoll, B.; Hipler, U.C.; Elsner, P. Melatonin suppress reactive oxygen species inUV-irradiated leukocytes more than vitamin C and trolox. Skin Pharmacol. Sppl. Skin Physiol. 2002, 15, 367-373. [CrossRef] [PubMed]

40. Fischer, T.W.; Slominski, A.; Zmijewski, M.A.; Reiter, R.J.; Paus, R. Melatonin as a major skin protectant from free radical scavengivg to DNA damage repair. Exp. Dermatol. 2008, 17, 713-730. [CrossRef]

41. Fischer, T.W.; Trueb, R.M.; Hanggi, G.; Innocenti, M.; Elsner, P. Topical melatonin for treatment of androgenetic alopecia. Int. J. Trichology 2012, 4, 236-245. [CrossRef]

42. Skobowiat, C.; Brozyna, A.; Janetovic, Z.; Jeang, S.; Oak, A.S.W.; Kim, T.K.; Paruch, U.; Reiter, R.J.; Slominski, A. Melatonin and its derivatives counteracts the ultraviolet B radiation-induced damage in human and porcine skin ex vivo. J. Pineal Res. 2018, 65, 1-16. [CrossRef]

43. Ozler, M.; Simsek, K.; Ozkan, C.; Akgul, E.O.; Topal, T.; Oter, S. Comparison of the effect of topical and systemic melatonin administration on delayed wound healing in rats that underwent pinealectomy. Scand. J. Clin. Lab. Investig. 2010, 70, 447-452. [CrossRef] [PubMed]

44. Song, R.; Ren, L.; Ma, H.; Hu, R.; Gao, H.; Wang, L.; Hen, X.; Zhao, Z.; Liu, J. Melatonin promotes diabetic wound healing in vitro by regulating keratinocyte activity. Am. J. Transl. Res. 2016, 8, 4682-4693. [PubMed]

45. Park, E.K.; Lee, H.J.; Lee, H.; Kim, J.H.; Hvang, J.; Koo, J.I.; Kim, S.H. The anti-wrinkle mechanism of melatonin in UVB treated HaCAT keratinocytes and hairless mice via inhibition of ROS and sonic hedgehog mediated inflammatory proteins. Int. J. Mol. Sci. 2018, 19, 1995. [CrossRef]

46. Slominski, A.; Pisarchik, A.; Semak, I.; Sweatman, T.; Wortsman, J.; Szczesniewski, A.; Slugocki, G.; McNulty, J.; Kauser, S.; Tobin, D.J. Serotonergic and melatonergic systems are fully expressed in human skin. FASEB J. 2002, 16, 896-898. [CrossRef]

47. Venegas, C.; García, J.A.; Escames, G.; Ortiz, F.; López, A.; Doerrier, C.; García-Corzo, L.; López, L.C.; Reiter, R.J.; AcuñaCastroviejo, D. Extrapineal melatonin: Analysis of its subcellular distribution and daily fluctuations. J. Pineal Res. 2012, 52, 217-227. [CrossRef] [PubMed]

48. Slominski, A.; Semak, I.; Fischer, T.W.; Kim, T.K.; Kleszczynski, K.; Haderland, R.; Reiter, R.J. Metabolism of melatonin in the skin.: Why is important? Exp. Dermatol. 2017, 26, 563-568. [CrossRef]

49. Haderland, R.; Tan, D.X.; Reiter, R.J. Kynuramines, metabolites of melatonin and other indoles: The resurrection of an almost forgotten class of biogenic amines. J. Pineal Res. 2009, 42, 109-126.

50. Liu, L.; Labani, N.; Cecon, E.; Jockers, J. Melatonin target proteins: Too many or not enough. Front. Endocrinol. (Lausanne) 2019, 10, 791. [CrossRef] [PubMed]

51. Slominski, A.; Haderland, R.; Zmijewski, M.A.; Slominski, R.M.; Reiter, R.J.; Paus, R. Melatonin: A cutaneous perspective on its production, metabolism and functions. J. Invest. Dermatol. 2018, 138, 490-499. [CrossRef]

52. Rusanova, I.; Martinez-Ruiz, L.; Florido, J.; Rodriguez-Santana, C.; Guerra-Librero, A.; Acuna-Castroviejo, D.; Escames, G. Protective effect of melatonin on the skin: Further perspectives. Int. J. Mol. Sci. 2019, 20, 4948. [CrossRef]

53. Boutin, J.A.; Ferry, G. Is there sufficient evidence that the melatonin binding site MT3 is quinone reductase 2? J. Pharm. Exp. Ther. 2019, 368, 59-65. [CrossRef]

54. Singh, M.; Jadhav, H.R. Melatonin function and ligands. Drug. Discov. Today. 2014, 19, 1410-1418. [CrossRef]

55. Xiong, J.; Wang, Z.; Cao, J.; Dong, Y.; Chen, Y. Melatonin mediates monochromatic light-induced proliferation of T/B lymphocytes in the spleen via the membrane receptors or nuclear receptor. Poult. Sci. 2020, 99, 4294-4302. [CrossRef]

56. Dai, J.; Ho, K.; Park, J.M.; Fischer, D.E. Topical ROR inverse agonists suppress inflammation in mouse models of atopic dermatitis and acute irritant dermatitis. J. Invest. Dermatol. 2017, 137, 2523-2531. [CrossRef] [PubMed]

57. Sunyer-Figueres, M.; Vazquez, J.; Mas, A.; Torija, M.J.; Beltran, G. Transcriptomic insight into the effect of melatonin in Saccharomyces cerevisiae in the presence and absence of oxidative stress. Antioxidants (Basel) 2020, 9, 947. [CrossRef] [PubMed]

58. Acuna-Castroviejo, D.; Lopez, L.C.; Escames, G.; Lopez, A.; Garcia, J.A.; Reiter, R.J. Melatonin-mitochondria interplay in health and disease. Curr. Top. Med. Chem. 2011, 11, 221-240. [CrossRef] 
59. García, J.J.; Lõpez-Pingarrõn, L.; Almeida-Souza, P.; Tres, A.; Escudero, P.; García-Gil, F.A.; Tan, D.X.; Reiter, R.J.; Ramírez, J.M.; Bernal-Pérez, M. Protective effects of melatonin in reducing oxidative stress and in preserving the fluidity of biological membranes: A review. J. Pineal Res. 2014, 56, 225-237. [CrossRef]

60. Reiter, R.J.; Ma, Q.; Sharma, R. Melatonin in mitochondria: Migrating clear and present dangers. Physiology (Bethesda) 2020, 35, 86-95. [CrossRef]

61. Beaupre, L.M.M.; Brown, G.M.; Gonçalves, V.F.; Kennedy, J.L. Melatonin's neuroprotective role in mitochondria and its potential as a biomarker in aging, cognition and psychiatric disorders. Transl. Psychiatry 2021, 11, 339. [CrossRef] [PubMed]

62. Martín Giménez, V.M.; de las Heras, N.; Ferder, L.; Lahera, V.; Reiter, R.J.; Manucha, W. Potential Effects of Melatonin and Micronutrients on Mitochondrial Dysfunction during a Cytokine Storm Typical of Oxidative/Inflammatory Diseases. Diseases 2021, 9, 30. [CrossRef] [PubMed]

63. Kopustinskiene, D.M.; Bernatoniene, J. Molecular Mechanisms of Melatonin-Mediated Cell Protection and Signaling in Health and Disease. Pharmaceutics 2021, 13, 129. [CrossRef]

64. Jou, M.J. Melatonin preserves the transient mitochondrial permeability transition for protection during mitochondrial $\mathrm{Ca}^{2+} \mathrm{stress}$ in astrocyte. J. Pineal Res. 2011, 50, 427-435. [CrossRef]

65. Fang, Y.; Zhao, C.; Xiang, H.; Jia, G.X.; Zhong, R. Melatonin improves cryopreservation of ram sperm by inhibiting mitochondrial permeability transition pore opening. Reprod. Domest. Anim. 2020, 55, 1240-1249. [CrossRef] [PubMed]

66. Bejarano, I.; Redondo, P.C.; Espino, J.; Rosado, J.A.; Paredes, S.D.; Barriga, C.; Reiter, R.J.; Pariente, J.A.; Rodriquez, A.B. Melatonin induces mitochondrial-mediated apoptosis in human myeloid hl-60 cells. J. Pineal Res. 2009, 46, 392-400. [CrossRef] [PubMed]

67. Reiter, R.J.; Sharma, R.; de Campos Zuccari, D.A.P.; de Almeida Chuffa, L.G.; Manucha, W.; Rodriguez, C. Melatonin synthesis in and uptake by mitochondria: Implications for diseased cells with dysfunctional mitochondria. Future Med. Chem. 2021, 13, 335-339. [CrossRef]

68. Galano, A.; Tan, D.X.; Reiter, R.J. Melatonin: A versatile protector against oxidative DNA damage. Molecules 2018, 23, 530. [CrossRef] [PubMed]

69. Janetovic, Z.; Jarret, S.G.; Lee, E.F.; Duprey, C.; Reiter, R.J.; Slominski, A.T. Melatonin and its metabolites protect human melanocytes against UVB-induced damage. Involvement of NRF2-mediated pathways. Sci. Rep. 2017, 7, 1274. [CrossRef]

70. Fischer, T.W.; Kleszczynski, K.; Hardkop, L.H.; Kruse, N.; Zillikens, D. Melatonin enhances antioxidative enzyme gene expression (CAT, GPx, SOD), prevents their UVR-induced depletion, and protects against the formation of DNA damage (8-hydroxy-20deoxyguanosine) in ex vivo human skin. J. Pineal Res. 2013, 54, 303-312. [CrossRef]

71. Santofimia-Castano, P.; Clea Ruy, D.; Garcia-Sanchez, L.; Jimenez-Blasco, D.; Fernander-Bezmejo, M.; Bolanos, J.P.; Salido, G.M.; Gonzales, A. Melatonin induces the expression Nrf2-regulated antioxidant enzymes via PKC and $\mathrm{Ca}^{2+}$ influx activation in mouse isolated acinar cells. Free Radic. Biol. Med. 2015, 87, 226-236. [CrossRef]

72. Sun, T.C.; Liu, X.C.; Yang, S.A.; Song, L.L.; Zhu, S.J.; Deng, S.L.; Tiang, L.; Chen, L.Y. Melatonin inhibits oxidative stress and apoptosis in cryopreserved ovarian tissue via Nrf2/HO-1 signaling pathway. Front. Mol. Biosci. 2020, 7, 163. [CrossRef]

73. Kleszczynski, K.; Zillikens, D.; Fischer, T.W. Melatonin enhances mitochondrial ATP synthesis, reduces reactive oxygen species formation, and mediates translocation of the nuclear erythroid 2-related factor 2 resulting in activation of phase-2 antioxidant enzymes (GCS, HO-1, NQO1) in ultraviolet radiation-treated normal human epidermal keratinocytes (NHEK). J. Pineal Res. 2016, 61, 187-197.

74. Bekyarova, G.; Tzaneva, M.; Hristova, M. Melatonin protects against burn-induced hepatic oxidative injury by inducing HO-1 via the Nrf2 pathway. Vet. Med. (Praha) 2015, 60, 621-628. [CrossRef]

75. Meena, R.; Kumari, K.; Kumar, J.; Rajamani, P.; Verma, H.N.; Kesari, K.K. Therapeutic approaches of melatonin in microwave radiations-induced oxidative stress-mediated toxicity on male fertility pattern of wistar rats. Electromagn. Biol. Med. 2014, 33, 81-91. [CrossRef] [PubMed]

76. Sokolovic, D.; Djordjevic, B.; Kocic, G.; Stoimenov, T.J.; Stanojkovic, Z.; Sokolovic, D.M.; Veljkovic, A.; Ristic, G.; Despotovic, M.; Milisavljevic, D.; et al. The effects of melatonin on oxidative stress parameters and DNA fragmentation in testicular tissue of rats exposed to microwave radiation. Adv. Clin. Exp. Med. 2015, 24, 429-436. [CrossRef]

77. Rezapoor, S.; Shirazi, A.; Abbasi, S.; Bazzaz, J.; Izadi, P.; Rezaeejam, H.; Valizadeh, M.; Soleimani-Mohammadi, F.; Najafi, M. Modulation of radiation-induced base excision repair pathway gene expression by melatonin. J. Med. Phys. 2017, 42, 245-250. [PubMed]

78. Valizadeh, M.; Shirazi, A.; Izadi, P.; Tavakkoly Bazzaz, J.; Rezaeejam, H. Expression levels of two dna repair-related genes under 8 gy ionizing radiation and $100 \mathrm{mg} / \mathrm{kg}$ melatonin delivery in rat peripheral blood. J. Biomed. Phys. Eng. 2017, 7, 27-36.

79. Mannino, G.; Caradonna, F.; Cruciata, I.; Lauria, A.; Perrone, A.; Gentile, C. Melatonin reduces inflammatory response in human intestinal epithelial cells stimulated by interleukin-1ß. J. Pineal. Res. 2019, 67, e12598. [CrossRef]

80. Wang, Y.; Zhao, T.T.; Zhao, H.Y.; Wang, H. Melatonin protects methotrexate-induced testicular injury in rats. Eur. Rev. Med. Pharmacol. Sci. 2018, 22, 7517-7525.

81. Shin, I.S.; Park, J.W.; Shin, N.R.; Jeon, C.M.; Kwon, O.K.; Ki, J.S.; Kim, J.C.; Oh, S.R.; Ahn, K.S. Melatonin reduces airway inflammation in ovalbumin-induced asthma. Immunobiology 2014, 219, 901-908. [CrossRef]

82. Favero, G.; Franceschetti, L.; Bonomi, F.; Rodella, L.R.; Rezzani, R. Melatonin as an anti-inflammatory agent modulating inflammasome activation. Int. J. Endocrinol. 2017, 2017, 1835195. [CrossRef]

83. Haderland, R. Aging, melatonin and the pro- and anti-inflammatory networks. Int. J. Mol. Sci. 2019, $20,1223$. 
84. Bonomi, F.; Dos Santos, M.; Veronese, F.V.; Rezzani, R. NLRP3 inflammasome modulation by melatonin supplementation in chronic pristane-induced lupus nephritis. Int. J. Mol. Sci. 2019, 20, 3466. [CrossRef] [PubMed]

85. Ashrafizadeh, M.; Najafi, M.; Kavyani, M.; Mohammadinejad, R.; Farkhondeh, T.; Samarghandian, S. Anti-inflammatory activity of melatonin: A focus on the role of NLRP3 inflammasome. Inflammation 2021, 44, 1207-1222. [CrossRef] [PubMed]

86. Carrillo-Vico, A.; Lardone, P.J.; Alvarez-Sanchez, N.; Rodriguez-Rodriguez, A.; Guerrero, J.M. Melatonin. Buffering the immune system. Int. J. Mol. Sci. 2013, 14, 8638-8683. [CrossRef] [PubMed]

87. Kuklina, E.M.; Glebezdina, N.S.; Nekrasova, I.V. Role of melatonin in the regulation of differentiation of T cells producing interleukin 17 (IL-17). Bull. Exp. Biol. Med. 2016, 160, 656-658. [CrossRef]

88. PubMed. Available online: https:/ / pubmed.ncbi.nlm.nih.gov (accessed on 8 June 2021).

89. Schwarz, W.; Birau, N.; Hornstein, O.P.; Heubeck, B.; Schonberger, A.; Meyer, C.; Gottschalk, J. Alterations of melatonin secretion in atopic dermatitis. Acta Derm. Venerol. 1988, 68, 224-229.

90. Kimata, H. Laughter elevates the levels of breast-milk melatonin. J. Psychosom. Res. 2007, 62, 699-702. [CrossRef]

91. Kimata, H. Elevation of salivary melatonin levels by viewing a humorous film in patients with atopic eczema. Horm. Metab. Res. 2007, 39, 310-311. [CrossRef]

92. Munoz-Hoyos, A.; Espin-Quirantes, C.; Molina-Carballo, A.; Uberos, J.; Contreraz-Chova, F. Neuroendocrine and circadian aspects (meatonin and beta-endorphin) of atopic dermatitis in the child. Pediatr. Allergy Immunol. 2007, 18, 679-686. [CrossRef]

93. Chang, Y.S.; Chou, Y.T.; Lee, J.H.; Lee, P.L.; Dai, T.S.; Sun, C.; Lin, Y.T.; Wang, L.C.; Yu, H.H.; Yang, Y.H.; et al. Atopic dermatitis, melatonin and sleep disturbances. Pediatrics 2014, 134, e397-e405. [CrossRef]

94. Uysal, P.; Avcil, S.; Abas, B.I.; Yenisey, C. Evaluation of oxidant-antioxidant balance in children with atopic dermatitis: A casecontrol study. Am. J. Clin. Dermatol. 2016, 1795, 527-537. [CrossRef] [PubMed]

95. Devadasan, S.; Sarkar, R.; Barman, A.D.; Kaushik, S. Role of serum melatonin and oxidative stress in childchood atopic dermatitis: A prospective study. Indian. Dermatol. Online J. 2020, 11, 925-929. [PubMed]

96. Chang, Y.S.; Lin, M.H.; Lee, J.H.; Lee, P.L.; Dai, Y.S.; Chu, K.H.; Sun, C.; Lin, Y.T.; Wang, L.C.; Yu, H.H.; et al. Melatonin supplementation for children with atopic dermatitis and sleep disturbance: A randomized clinical trial. JAMA Pediatr. 2016, 170, 35-42. [CrossRef]

97. Ardakani, A.T.; Farrehi, M.; Sharif, M.R.; Ostadmohammadi, V.; Mirhosseini, N.; Kheirkhah, D.; Moosavi, S.G.A.; Behnejad, M.; Reter, R.J.; Asemi, Z. The effects of melatonin administration on disease severity and sleep quality in children with atopic dermatitis. A randomized, double-blinded, placebo-controlled trial. Pediatr. Allergy Immunol. 2018, 29, 834-840. [CrossRef] [PubMed]

98. Kim, T.-H.; Jung, J.-A.; Kim, G.-D.; Jang, A.-H.; Ahn, H.-J.; Park, Y.S.; Park, C.-S. Melatonin inhibits the development of 2,4-dinitrofluorobenzene-induced atopic dermatitis-like skin lesions in NC/Nga mice. J. Pineal Res. 2009, 47, 324-329. [CrossRef]

99. Park, G.; Lee, S.H.; Oh, D.S.; Kim, Y.U. Melatonin inhibits neuronal dysfunction-associated with neuroinflammation by atopic psychological stress in an NC/Nga atopic-like mouse model. J. Pineal Res. 2017, 63. [CrossRef]

100. Park, G.; Jung, Y.S.; Park, M.K.; Yang, Y.H.; Kim, Y.U. Melatonin inhibits attention-deficit/hyperactivity disorder caused by atopic dermatitis-induce psychological stress in an NC/Nga atopic-like mouse model. Sci. Rep. 2018, 8, 14981. [CrossRef]

101. Crowley, S.J.; Acebo, C.; Carskadon, M.A. Human puberty, salivary melatonin profiles in constant conditions. Dev. Psychobiol. 2012, 54, 468-473. [CrossRef] [PubMed]

102. Esposti, D.; Lissoni, P.; Mauri, R.; Rovelli, F.; Orsenigo, L.; Pescia, S.; Vegetti, G.; Esposti, G.; Fraschini, F. The pineal gland-opioid system relation: Melatonin-naloxone interactions in regulating GH and LH releases in man. J. Endocrinol. Invest. 1988, 11, 103-106. [CrossRef]

103. Bertino, L.; Guarneri, F.; Cannavò, S.P.; Casciaro, M.; Pioggia, G.; Gangemi, S. Oxidative Stress and Atopic Dermatitis. Antioxidants 2020, 9, 196. [CrossRef] [PubMed]

104. Gurer-Orhan, H.; Suzen, S. Melatonin, its metabolites and its synthetic analogs as multi-faceted compounds: Antioxidant, prooxidant and inhibitor of bioactivation reactions. Curr. Med. Chem. 2015, 22, 490-499. [CrossRef] [PubMed]

105. Suzen, S.; Cihaner, S.S.; Coban, T. Synthesis and comparison of antioxidant properties of indole-basedmelatonin analogue indole amino acid derivatives. Chem. Biol. Drug Des. 2012, 79, 76-83. [CrossRef] [PubMed]

106. Jaworek, J.; Szklarczyk, J.; Bonior, J.; Kot, M.; Pierzchalski, P.; Góralska, M.; Reiter, R.J.; Czech, U.; Tomaszewska, R. Melatonin metabolite N(1)-acetyl-n(1)-formyl-5-methoxykynuramine (AFMK) attenuates acute pancreatitis in the rat in vivo and in vitro. $J$. Physiol. Pharmacol. 2016, 67, 311-321.

107. Jaworek, J.; Leja-Szpak, A.; Nawrot-Porabka, K.; Szklarczyk, J.; Kot, M.; Pierzchalski, P.; Góralska, M.; Ceranowicz, P.; Warzecha, Z.; Dembinski, A.; et al. Effects of melatonin and its analogues on pancreatic inflammation, enzyme secretion and tumorigenesis. Int. J. Mol. Sci. 2017, 18, 1014. [CrossRef] 